\title{
Öğrencilerin Alaeddin Keykubad Kampüsü Fiziksel Çevresine İlişkin Güvenlik Algıları
}

\author{
DOI: $10.26466 /$ opus.453200
}

\begin{abstract}
$\underline{\text { Filiz Celik }}^{*}$ - R. Özge Gemici ${ }^{* *}$ - Esra Mirza ${ }^{\star * *}$
*Dr. Öğr. Üyesi, Selçuk Üniversitesi, Ziraat Fakültesi, Peyzaj Mimarlığı Böl. Konya/Türkiye E-Posta: filiz@selcuk.edu.tr ORCID: 0000-0002-4006-5947 ** Öğr. Görevlisi, Selçuk Üniversitesi, Ziraat Fakültesi, Peyzaj Mimarlığı Böl. Konya/Türkiye E-Posta: ozgeocak@selcuk.edu.tr ORCID: 0000-0001-7477-0268

*** Doktora Öğr., Süleyman Demirel Üniversitesi, Fen Bilimleri Enstitüsü. Isparta/Türkiye E-Posta: $\underline{\text { mirzaesra@hotmail.com }}$ ORCID: $\underline{0000-0002-6731-7745}$
\end{abstract}

\section{Öz}

Üniversite kampüsleri, idari birimler, eğitim-öğretim binaları, öğrenci yurtları, lojmanlar, misafirhane, konferans salonu, açık ve kapalı spor alanları, dini yapı, sağllk tesisi, yeme-içme ve alış-veriş mekanları, ulaşım ağı, otoparklar ve yeşil alanlar gibi sosyal donatıların yer aldığı kendi içinde kapalı bir yerleşmedir. Bu yönüyle üniversite kampüsleri, küçük bir kent gibidir. Kentlerde olduğu gibi kampüslerin de geniş bir alana sahip olması, yetersiz aydınlatma, ıssız ve köhne yerler, başıboş hayvanlar, yabancllar ve suç korkusu gibi nedenler kampüsün kontrolünü zorlaştırıp savunmasız hale getirmektedir. Bu nedenle zaman zaman kampüsler güvenlik ihtiyacı ve suç korkusunun arttığı yerler haline gelmektedir. Fiziksel çevrenin neden olduğu güvenlik ve güvensizlik algısı, kampüsteki huzur ortamı, yaşam kalitesi, konfor seviyesi, düzen ve sosyal kontrolü etkilemektedir. Öğrencilerin yanı sıra akademik ve idari personelin dış mekanları kullanmasını doğrudan etkilediğgi için güvenlik algısı kampüsün yaşanabilirliğini ve hareketliliğini de etkileyen bir faktördür. Bu araştırmanın amacı, anket ve ölçek tekniğine dayalı niceliksel sorgulama yöntemine göre öğrencilerin, Alaeddin Keykubad Kampüsü fiziksel çevresine ilişkin, güvenlik algılarını belirlemektir. Niceliksel veriler doğrultusunda kampüsün fiziksel özelliklerinin öğrencilerin güvenlik algılarını nasıl etkilediği ve kampüste öğrenciler tarafindan güvenli-güvensiz algzlanan yerler belirlenmiştir. Elde edilen veriler doğrultusunda kampüste öğrencilerin güvenlik algısın arttıracak önerilere yer verilmiştir.

Anahtar Kelimeler: Güvenlik, Güvenlik algısl, Kampüs güvenliği, Selçuk Üniversitesi, Alaeddin Keykubad Kampüsü 


\title{
Students' Perceptions of Security Related to Alaeddin Keykubad Campus' Physical Environment
}

\begin{abstract}
University campuses are close habitations in themselves where social reinforcements, such as administrative units, education buildings, dormitories, lodgements, guest house, conference hall, outdoor and indoor sports hall, religious construction, health facility, food-beverage and shopping places, transportation network, parking area and green spaces, are located. With this aspect, university campuses are like small cities. As in cities, causes like having a wide area of campuses, inadequate lighting, desolate and fusty places, stray animals, strangers and fear of crime make controlling of campus hard and indefensible. Therefore; from time to time, campuses become places in which safety need and fear of crime increase. Physical environment causes perception of security and insecurity, and influences peaceful atmosphere, quality of life, comfort level, layout and social control in campus. In addition to students, for the fact that academic and administrative personnel directly influence using of outer spaces, the perception of security is a factor affecting inhabitability and liveliness of campus. This research's aim is to determine the perceptions of security of students related to physical environment of Alaeddin Keykubad Campus in regard to the method of quantitative questioning based on the technique of survey and scale. In direction with quantitative data, it is determined how physical features of campus affect the perceptions of security of students and secure-insecure places perceived by students in campus. In direction with obtained data, suggestions are included to raise the perception of security of students in campus.
\end{abstract}

Keywords: Campus security, Security, Security perceptions, Selçuk University, Alaeddin Keykubad Campus 


\section{Giriş}

İnsanın davranışları, istek ve ihtiyaçlarını karşılayan fiziksel ve sosyal çevrelerde ortaya çıkmaktadır. İnsanın temel ihtiyaçları arasında yer alan güvenlik, insan davranışlarını belirleyen bir ihtiyaç olup aynı zamanda mekan kullanımını ve mekanla ilgili tercihlerini de etkilemektedir. Davranışın en güçlü belirleyicisi olan güvenlik algısı, sosyal ve fiziksel çevrede, insanın davranışları üzerinde etkili bir rol oynamaktadır.

Birey içinde yaşadığ setmek ister. Güvensizlik duygusu bireyde kaygı, korku ve endişeye neden olur. Kendini güvende hissetmeyen bireylerin oluşturduğu toplumlarda birçok sorun ortaya çıar. Toplumsal gerilim ve baskı, öfke ve şiddete neden olur (Öztürk, 2015, s. 55).

Güvenlik ihtiyacı, kendini güven ve emniyet içinde tehlikeden uzak hissetme, korunma, barınma, korku ve kaygidan uzak durma ve bunun içinde kural ve yasalara olan gereksinimlerden meydana gelmektedir (Maslow, 1943). Maslow'un ihtiyaçlar hiyerarşisinde ${ }^{1}$ sıraladığı gibi güvenli bir ortam ihtiyacı çoğunlukla insanların diğer ihtiyaçlarının önüne geçmektedir. Güvenlik, mekanın deneyimlenmesi sonucu oluşan bir duygu ve algıdır. Fiziksel çevrenin niteliği, tasarım özellikleri, içinde barındırdığı unsurlar ve çevre koşulları bireylerin güvenlik duygusunu ve suç korkusunu etkilemektedir (Şahin, 2016, s. 107). Kişilerin mekanı nasıl algıladıkları ve mekanın kişilerde ortaya çıkardığı farklı algılara neden olan fiziksel özellikleri güvenlik algısı, suç tehdidi ve suç olaylarının ortaya çıkmasında etkili olmaktadır (Apak, Ülken ve Ünlü, 2002).

Güvenlik algısı, bireye (yaş, cinsiyet), topluma, zamana, duruma, mekana, sosyo-ekonomik ve kültürel özelliklere göre farklılık gösterebilmektedir. Bu bağlamda nesnel olmaktan çok öznel bir durum olan güvenlik algısı değişken bir özelliğe de sahiptir. Güvenlik veya güvensizlik, bireyin içinde bulunduğu durumu algılama sonrasında korku, risk, tehdit ve tehlike kavramlarıyla birlikte ifade edilmektedir (Çelik, 2018, s. $60)$.

\footnotetext{
${ }^{1}$ Maslow ihtiyaçlar hiyerarşisi teorisinde; insanın temel ihtiyaçlarını önemine göre fizyolojik ihtiyaçlar, güvenlik ihtiyacı, sosyal ihtiyaçlar, ait olma ve sevgi ihtiyacı, değer ve saygınlık ihtiyacı, kendini gerçekleştirme ihtiyacı sırasıyla giderdiğini öne sürmüştür (Maslow, 1943).
} 
Güvenlik ve suç korkusu algısı, sosyal çevre ve fiziksel çevreye bağl1dır. Güvensizliğe neden olan suçun, fiziksel çevreyle doğrudan ilişkili olduğu bilinmektedir. Bu nedenle suç korkusu fiziksel çevrenin özelliklerinden kaynaklanabilmektedir. Suç ve insanlar üzerinde oluşturduğu korku, insanların günlük yaşamını önemli ölçüde etkilemektedir. Açık alanların sağladığı fiziksel özelliklerin bir sonucu olarak, bazı alanlar yoğun olarak kullanılırken bazı alanlar ise 1ssız, terk edilmiş alanlara dönüşmektedir. Korku ve güvensizlik, hem insanların yaşam kalitesini düşüren hem de toplumda onarılması en zor olan sosyal sorundur. Kendini güvende hissetmeyen bir insan fiziksel ve sosyal çevreden kopabilir, temel ihtiyaçlarını karşılayamaz, yaşam kalitesi düşer ve sonuçta mutsuz biri haline dönüşür.

Bu çalışmanın temel amacı; Selçuk Üniversitesi öğrencilerinin Alaeddin Keykubad Kampüsü fiziksel çevresine ilişkin güvenlik algılarını belirlemektir. Bu amaçla anket uygulanmış; elde edilen niceliksel veriler doğrultusunda Alaeddin Keykubad Kampüsü'nün güvenli ve güvensiz olduğu yerler belirlenmiş; daha güvenli bir kampüs için önerilere yer verilmiştir.

\section{Üniversite Kampüslerinde Güvenlik}

Güvenli bir kampüs öğrencilere akademik potansiyellerini, ayrımcılık ve sindirmeden uzak ya da fiziksel ve psikolojik esenliklerine yönelik tehdit içermeyen bir ortamda sürdürme olanağı sağlayan bir kampüstür. Güvenli bir kampüs, güvenlik için izlenen, fiziksel çevrenin rutin olarak izlendiği ve uygun şekilde düzenlemelerin yapıldığı bir yerdir. Böyle bir fiziksel çevrenin oluşturulması, kurumsal bir sorumluluktur ve kurum içinde birden çok tarafın katılımını ve taahhüdünü gerektirir. Kampüste güvenlik için genellikle birincil rolü öğrencilerin refahıla ilgilenmekle yükümlü olan güvenlik birimi ve öğrenci işleri sorumludur. Kampüste güvenliği sağlamak için tehditleri ortadan kaldırarak kararlı ve düzeltici önlemler alınmalıdır (Rund, 2002, s. 8).

Güvenli kampüs, öğrenci, akademisyen ve üniversite çalışanlarının kendilerini fiziksel, psikolojik ve sosyal bakımdan özgür hissettikleri yerdir. Güvenli kampüs, yüksek ölçekli güvenlik algısına ve uygulamalarına sahip, özgür ve güvenli bir iklimi, birbirine değer veren, üniversi- 
teye bağlılık hissiyle dolu akademik ve evrensel eğitime odaklanmış öğrenci ve öğretim üyeleri, uyum ve uzlaşıyla oluşturulmuş kuralları, olası suç olgularına karşı önceden saptanmış plan ve projeleri bulunan proaktif bir güvenlik algısının etkin ve yetkin olduğu, sosyal, sanatsal, sportif ve kültürel etkinliklerle renklendirilmiş bahçesi gençlerle canlanan bir kampüstür. Güvenli bir kampüs ortamı öğrenciler için okula bağlılık, derslere odaklanma ve akademik başarıyı da beraberinde getirmektedir (Öztürk, 2014, s. 50).

Kelly ve Torres (2006), “Campus Safety: Perceptions and Experiences of Women Students" (Kampüs Güvenliği: Kız Öğrencilerin Algıları ve Deneyimleri) başlıklı çalışmalarında ABD'de bir üniversitedeki lisans ve lisansüstü kız öğrencilerin kampüs güvenliğiyle ilgili deneyimlerini incelenmişlerdir. Amaçlı örnekleme yöntemi kullanarak 31 lisans, 15 lisansüstü öğrencisi olmak üzere toplam 46 öğrenciye kampüste güvenlikle ilgili geçmiş tecrübelerini içeren bir anket uygulaması yapmışlardır. Daha sonra 4-12 katılımcıdan oluşan 8 odak grubu ile yüz yüze görüşmeler yapılmış; yüz yüze görüşmeler ile öğrencilerin kendi fikirlerini ve diğer öğrencilerle etkileşimde bulunarak deneyimlerini daha iyi ifade edebilmeleri hedeflenmiştir. Sabit karşılaştırma yöntemi kullanılarak veriler değerlendirilmiştir. Çalışmada genel olarak kız öğrenciler kampüste güvenlikleri hakkında korku ve endişelerini; geceleri kampüste yürümekten ve cinsel saldırıya uğramaktan korktuklarını dile getirmişlerdir. Ayrıca fiziksel saldırı, uyuşturucu ve hırsızlık gibi suçlardan da korkmaktadırlar. Bu çalışmada ırk, üniversite sınıflandırması ve katılım düzeyine göre kız öğrenciler kampüs güvenliği için hissettikleri korkuyu sürdürmeye hizmet eden soğuk bir kampüs ortamı olduğu sonucuna varılmıştır.

Muscat'in (2011), “Rowan University Students' Perceptions of Campus Safety" (Rowan Üniversitesi Öğrencilerinin Kampüs Güvenliği Alg1ları) isimli tez çalışmasının temel amacı öğrencilerin kampüse ilişkin güvenlik algılarını incelemektir. Bu çalışma, 2011 yılı bahar Rowan Üniversitesi'nde 1.070 öğrencinin katılımıyla gerçekleşmiştir. Çalışmada öğrencilerin cinsiyet, yaş, ırk gibi demografik özellikler, sınıfı, ülkesi/şehri ve suç mağduriyeti geçmişi gibi faktörlerin etkisini araştırmıştır. Öğrencilerin güvenlik algısına ilişkin veriler 1-5 Likert ölçeğinde açık uçlu, çoktan seçmeli sorular ve isteğe bağlı yorumlardan oluşan bir anket 
ile toplanmıştır. Anket soruları demografik bilgiler, kampüs güvenliği, topluluk duygusu, kampüsün fiziksel ortamı, kamu güvenliği hizmetlerinin kullanımı ve genel algılar başlıkları altında gruplandırılmıştır. Katılımcıların çoğunluğu, genel olarak kampüste kendilerini güvende hissettiklerini ve Rowan'ın Kamu Güvenliği yetkililerinin profesyonel olduğunu düşündüklerini bildirmiştir.

ABD Eğitim Bakanlığı'na bağlı CSS (Campus Safety and SecurityKampüs Emniyeti ve Güvenliği) biriminin yapmış olduğu “The Campus Safety and Security Data Analysis" (Kampüs Emniyeti ve Güvenlik Veri Analizi) çalışması;

- Bir okul veya kampüs için genel bilgileri ve son üç yıl boyunca güvenlik ve güvenlikle ilgili istatistiksel verileri görüntüleme,

- Birden çok okul veya kampüs için verileri karşılaştırma,

- Özel verileri indirme (bir veya daha fazla yıla ait güvenlik ve güvenlikle ilgili istatistiksel verileri ve bir okul/kampüs için veri indirme),

- Güncel verileri oluşturma,

- Veri indirme (seçilen anket yılındaki tüm kurumlar tarafından sunulan tüm veri dosyasını indirme) imkanı sunmaktadır (U.S. Department of Education, 2018).

\section{Güvenlik algısında kampüsün fiziksel çevresinin etkisi}

Fiziksel çevre, belirli bir bölgede meydana gelebilecek olaylar nedeniyle sınırlamalar yaratarak insan davranışını etkilemektedir. İnsanın fiziki çevre hakkındaki bilgisi, buna kampüsler de dahil olmak üzere ortam hakkında seçim yapmak ve hareket etmek için kritik ipuçları vererek pratik yarar sağlayabilir. Fiziksel çevrenin öğeleri, bireysel farklılıklara rağmen insan davranışlarına izin verebilir veya sınırlayabilir çünkü insanın içinde bulunduğu fiziki ortam, davranışlarını belirleyebilir ve etkileyebilir (Miller, 2011, s. 29).

Lenski (1992), öğrencilerin davranışsal niyetlerini tahmin etmek için “Güvenlik İnanç Modeli”ni² kullanarak "Kampus Güvenlik Araştırma-

\footnotetext{
2 Güvenlik Inanç Modeli, değişken grupların, davranış niyetiyle ilişkili olarak güvenlik inançları dizisini vurgulayan ölçeklerdir (Lenski, 1992).
} 
s1"nı gerçekleştirmiştir. Araştırma sonucunda, bir öğrencinin suç mağduriyetini azaltmak için tedbirli adımlar atmayı planlayıp/planlamadığını tahmin etmek için önemli bir güce sahip olduğu sonucuna varmıştır. Lenski ve arkadaşlarının (1996) çalışmasında ise öğrencilerin güvenlik algısını belirlerken demografik bilgileri ve önceki yaşam deneyimlerini bir araya getirerek öğrencilerin amaçlanan davranışlarını tahmin etmenin mümkün olduğu sonucuna varmışlardır.

Üniversitelerin, güvenlik konularını gündemden uzak tutması yerine kampüslerin 'insanlığın yetiştirilmesi' için uygun bir çevre yaratılması hedef olmalıdır. Bu nedenle insancil prensiplere ek olarak, zararlı yaptırımlara karşı koyan, şefkatli davranışları destekleyen sosyal sistemlerle birlikte güvenlik önlemleri uygulanmalıdır. Bu nedenle, hedef güçlendirme uygulamalarıyla ilgili üniversite politikaları, insanlık dışı ve/veya suç davranışları önleme aracı olarak, öğrencilerin algılarına ve dolayısıyla dış tehditlerden gelen mağduriyet korkusuna katkıda bulunmaktadır. Öğrencilerin suç ve mağduriyet korkusu hakkındaki algılarını anlamak, en etkili müdahalelerin geliştirilmesi için çok önemlidir. Robinson, fiziksel çevrenin, kişinin kişisel güvenlik riskinin varlığına ilişkin algısını etkileyebileceğini ama mağduriyetten korkmadığını ya da kişinin kişisel güvenlik riski ve suç korkusu olarak algılayabileceğini fark etmiştir. Her iki senaryoda da bu algılar ve korkular haklı olabilir ya da olmayabilir.

Roberts'in kampüs güvenliğini kapsayan "Keeping Students Safe: Student Perceptions of Campus Safety at a Mid-Sized Virginia University and the Impact for Prevention, Response and Risk Reduction Strategies" (Öğrencilerin Güvenliğini Sağlamak: Orta Büyüklükteki Bir Virginia Üniversitesinde Öğrencilerin Kampüs Güvenliği Algıları ve Öğrencilerin Önleme, Müdahale ve Risk Azaltma Stratejileri Üzerindeki Etkisi) başlıklı araştırması, öğrencilerin algıları ve mağduriyet korkuları üzerindeki cinsiyet senaryolarının etkilerini tespit etmiştir, bu alg1 ve korkuları nasıl davranış veya stratejilerle yönetilecekleri ile ilgili kararlar ile sonuçlanmaktadır (Roberts, 2012, s. 51).

Bir üniversite kampüsünün ve tesislerinin tasarımı ve düzeni nedeniyle kişisel güvenlik konusu çok önemlidir. Kampüsler genellikle geniş açık alanlardır ve sistematik erişim kontrolünden yoksundurlar, bu da kampüs kullanıcılarının mağduriyet ve korku yaşamalarına zemin oluşturmaktadır. Araştırmalar, üniversite kampüslerindeki suç korkusunun 
fiziksel ortamın farklı özelliklerinden etkilenebileceğini ortaya koymaktadır. Kampüslerin tasarım özellikleri ve fiziksel düzenleriyle bağlantılı olarak belirli suçlara ve kişisel güvenlik kaygılarına neden olması, genç ve savunmasız öğrencilerin suç ve kişisel güvenlik olaylarını yaşamalarina neden olmaktadır (Waters, Neale ve Mears, 2005, s. 231).

Waters ve arkadaşlarının (2005), "Perceptions of Personal Safety in Relation to the Physical Environment of University Campuses" (Üniversite Kampüslerinin Fiziksel Çevresi ile İlgili Kişisel Güvenlik Algıları) çalışması, Glamorgan Üniversitesi'nde, öğrencilerin kampüs ortamının fiziksel özelliklerine vurgu yaparak üniversite kampüslerinde ve çevresinde kişisel güvenliğini nasıl algıladıklarına odaklanmıştır. Araştırmanın temel amacı, öğrencilerin olası tehdit ve savunmasızlıklarını ortaya çıkarmak; kampüsün fiziksel çevresini ve kullanıcıların kişisel güvenliklerine ilişkin algılarına dayanan tasarımın formu ve yönetim değişikliklerine yönelik çözümleri tanımlamaktır. Araştırma bulguları, Glamorgan Üniversitesi kampüsünün cesaret verici ve gün boyunca nispeten güvenli bir kampüsün genel portresini çizdiğini göstermektedir. Ancak fiziksel çevrede gecenin etkisi algıyı farklılaştırmaktadır. Bu durum kişisel güvenlik konusundaki endişeler üzerinde önemli bir etkiye sahiptir. Öğrencilerin kişisel güvenliklerini etkilediği tespit edilen konular arasında aydınlatma seviyeleri, kampüsün peyzajı, güvenlik ekipmanı, kampüsün fiziksel çevresi ve kurumsal açık erişim felsefesi yer almaktadır.

Froughisaeid (2018), “Bir Üniversite Kampüsünün Fiziksel Ortamında Güvenlik Algısı: Orta Doğu Teknik Üniversitesi Örneği” başlıklı tez çalışmasında kampüs ortamının fiziksel özelliklerinin öğrencilerin güvenlik algılarını nasıl etkilediğini ortaya çıkarmayı amaçlamıştır. Çalışmada, kampüste yaşama tecrübesine sahip olan 20-30 yaşları arasındaki 25 lisans ve lisansüstü öğrenciyle derinlemesine görüşmeler yaparak bilgi toplanmıştır. Araştırma kriterlerine uyan uluslararası ve yerli öğrenciler arasından katılımcları rastgele seçmiştir. ODTÜ yönetiminden 2009 ve 2017 yılları arasında taciz, hirsızlık ve hayvan saldırılarıyla ilgili ilave veriler toplamıştır. Verilerin analizi, tasarım problemlerinin öğrencilerin algıları ve günlük rutinleri üzerindeki etkisini ortaya koymuştur. Zayıf aydınlatma, kampüs merkezinden uzak bölgeler, yoğun bitki örtüsü ve yürüme zorlukları gibi öğrencilerin, resmi raporlara göre bu alanlarda daha az güvenlik sorunu olmasına rağmen daha az güvende hissettiği 
ortaya çıkmıştır. Kampüsün belirli bölgelerinde insanların bulunmaması ve ortak kullanılan mekanların olmamasının öğrencilerin Orta Doğu Teknik Üniversitesi Kampüsünde güvenlik algısını belirleyen en etkili unsurlar olduğu tespit edilmiştir.

\section{Kampüste güvenlik önlemleri}

Geçtiğimiz elli yıldan fazla zamanda kampüs güvenliği konusu yaygın bir konu haline gelmiş ve karmaşık bir mesele olduğu da kanıtlanmıştır (Roberts, 2012, s. 18). Jeanne Clery'in Kampüs Güvenlik Politikası ve Kampüs Suç İstatistikleri Kanunu'nun (The Jeanne Clery Disclosure of Campus Security Policy and Campus Crime Statistics Act) açıklanması, kampüslerin yurtdışındaki eğitim bürolarında güvenlikle ilgili politika ve prosedürlere ilişkin çıkarımlar içermektedir. Clery Yasası'nın esas amacı, halkın, ebeveynlerin, öğrencilerin ve potansiyel öğrencilerin suç düzeyine ve kampüste meydana gelen öğrenci alkol ve uyuşturucu ihlallerine dair doğru ve zamanında güvenlik bilgisi sağlamaktır. Raporda ayrıca kampüs güvenliği, suç raporlama, alkol ve uyuşturucu kullanımı, kurbanların yardım programları, öğrenci disiplini, kampüs kaynakları, toplum güvenliği uyarıları, suç önleme, kampüs tesislerine erişim ve kişisel güvenlik ile ilgili politika ve uygulamalar da yer almaktadır (Clery, 1986, s. 3). Bu kanun, üniversite polisinin günlük suç bilgilerini tutmasını ve duyurmasını, ayrıca kapsamlı bir kampüs güvenliği mevzuatı hazırlayarak bunu hayata geçirmesini öngörmüştür (Sözer ve Clevenger, 2010, s. 96).

Clery'nin üniversitelerin güvenlik konusunda yapmasını önerdiği çalışmalar:

- Üç̧ yıllık kampüs suç istatistikleri ve kampüs güvenlik politikası açılamalarını içeren yıllık bir rapor yayınlamak.

- Öğrencilere veya çalışanlara yönelik tehdit olduğu düşünülen herhangi bir suç, faaliyet ve kişiler hakkında derhal haberdar etmek veya uyarmak.

- Polis veya güvenlik biriminde (eğer varsa) öğrencilere açık bir suç günlüğünü oluşturmak ve sürekli hale getirmek.

- Kampüste yangın kaydını tutmak ve yıllık bir yangın güvenliği raporunu tek başına ya da yıllık suç istatistikleri ile birlikte rapor 
halinde yayınlamak.

- Cinsel saldırı kurbanlarına belirli haklar sağlamak ve seks suçluları hakkında bildiri yayınlamak.

- Yurtlarda öğrencilerin eksik olduğu bildirildikten sonra 24 saat içinde hemen harekete geçmektir.

Türkiye'de ise birbirinden farklı yapıya sahip devlet ve vakıf üniversitesi kampüslerinde ikili özel güvenlik yapısı mevcuttur. Kampüs güvenliği, 2495 sayılı yasaya göre özel güvenlik görevi yapan personel ile 5188 sayılı Özel Güvenlik Yasasına tabi özel güvenlik firmalarının özel güvenlik personeli tarafından yürütülmekte olup 7 gün 24 saat esasına göre kesintisiz hizmet vererek çalışmaktadırlar (Öztürk, 2014, s. 56; Uçkun, 2014, s. 59).

\section{MATERYAL VE YÖNTEM}

\section{Materyal}

Çalışma alanı, Selçuk Üniversitesi, Alaeddin Keykubad Kampüsü, Konya kent merkezinin $20 \mathrm{~km}$ kuzeyinde, Selçuklu İlçesi sınırları içinde ve Afyonkarahisar karayolu üzerinde yer almaktadır (Şekil 1). Kampüsün doğusunda Konya-Afyon karayolu, kuzeyinde Bilecik (Yükselen) Mahallesi, batısında Ardıçlı Mahallesi, güneyinde Beyhekim Mahallesi, güneydoğusunda Akademi Mahallesi yer almaktadır. Alaeddin Keykubad Kampüsü, 14,5 milyon $\mathrm{m}^{2}$ alana sahip olup binalar, yollar, otoparklar ve açık-yeşil alanların oluşturduğu bir bütündür.

$\mathrm{Bu}$ araştırmanın hedef kitlesi, Selçuk Üniversitesi, Alaeddin Keykubad Kampüsü'nde öğrenim gören ön lisans, lisans ve lisansüstü öğrencilerdir.

\section{Yöntem}

Güvenlik, insanların deneyimleri sonucunda ortaya çıan his ve duygularını ifade eder. Güvenlik algısını belirlemenin en etkin yolu, bireylerin yaşadıkları, çalıştıkları, eğitim gördükleri, eğlendikleri vb. yerler hakkında ne kadar güvende hissettikleri konusunda anket yapmaktır (Bedimo-Rung, Moven ve Cohen, 2005). 

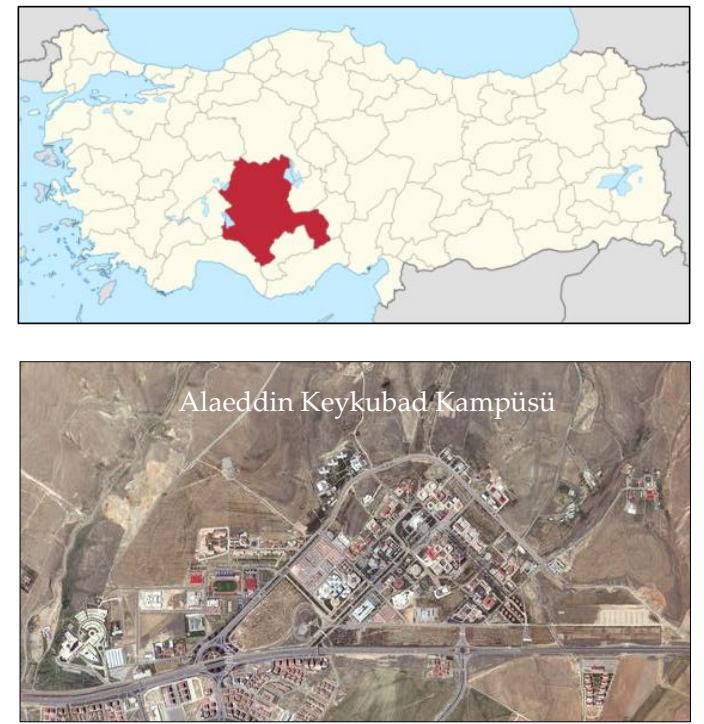

Şekil 1. Selçuk Üniversitesi, Alaeddin Keykubad Kampüsü'nün konumu

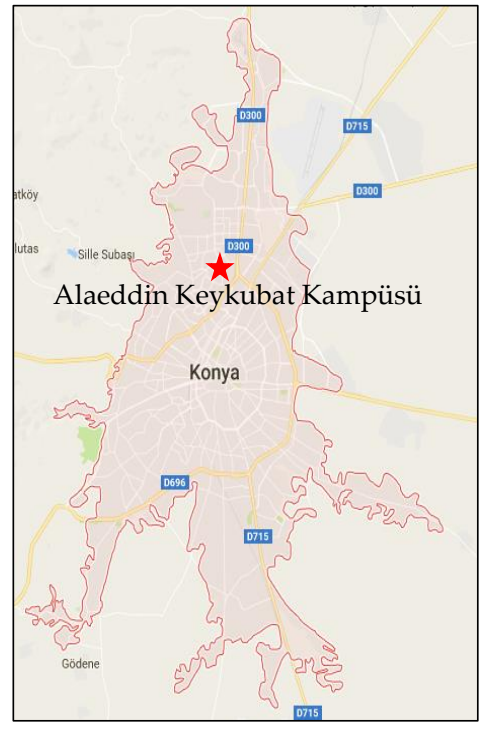

$\mathrm{Bu}$ çalışmada; anket ve ölçek tekniğine dayalı niceliksel sorgulama yöntemine göre öğrencilerin Alaeddin Keykubad Kampüsü'nün fiziksel çevresine ilişkin güvenlik algıları belirlenmeye çalışılmıştır. Araştırmada öğrencilerin kişisel bilgilerinin belirlenmesine yönelik kapalı uçlu anket sorularının yanı sıra kampüste güvenlik algısını belirlemek amacıyla oluşturulan ölçek kullanılmıştır. Kampüste güvenlik algısı düzeyini belirlemek için oluşturulan önermeler 5'li likert ölçeği ile derecelendirilmiştir. Sorular hazırlanırken "Kampüs Güvenliği ve Güvenlik Raporlaması El Kitabı" (The Handbook for Campus Safety and Security Reporting) (U.S. Department of Education, 2016) adlı çalışmadan ve alan çalışması sonucu yapılan tespitlerden yararlanılmıştır. Nisan (2018) ayında Alaeddin Keykubad Kampüsü'nde gündüz ve gece alan çalışması yapılmış, fotoğraf çekilmiş ve güvenlik açısından sıkıntı oluşturabilecek yerler ve durumlar belirlenmiştir. Alan çalışması sonucu yapılan tespitler, anket ve ölçek soruları hazırlanırken kullanılmıştır. Hazırlanan anket formunun güvenirliğini ve anlaşılırlı̆̆ını test etmek için ön uygulama yapılmış ve geri bildirimler doğrultusunda gerekli değişiklik yapılmıştır.

Araştırmanın örneklemini, Selçuk Üniversitesi, Alaeddin Keykubad Kampüsü'nde (merkez kampüs) öğrenim gören ön lisans, lisans ve lisan- 
süstü öğrencileri oluşturmaktadır. Alaeddin Keykubad Kampüsü'nde farklı fakülte, yüksekokul, meslek yüksekokulu, konservatuvar ve enstitülerde öğrenim gören ön lisans (15.660 öğrenci), lisans (44.880 öğrenci) ve yüksek lisans (14.975 öğrenci) ve doktora (2.268 öğrenci) öğrencisi olmak üzere toplam 77.783 öğrenci vardır (S.Ü., 2018). Araştırmanın amaçlarına göre basit tesadüfi örnekleme kullanılmış; zamanın sınırlandırıcı faktör olarak kabul edilmesiyle örneklem büyüklügü ortaya çımıştır. Kampüste öğrencilerin güvenlik algısını belirleme anketi, 1-30 Haziran 2018 tarihleri arasında uygulanmış ve 225 öğrenciden geri dönüş olmuştur. Araştırmada hedef kitlenin istekli olması ve daha sağlıklı cevaplar vermesi için öğrencilere e-posta ve sosyal medya üzerinden ulaşılmıştır. Verilerin çözümünde açıklayıcı faktör analizleri ile güvenirlik analizleri yapılmıştır. Güven aralığı $\% 95$ ve anlamlılık düzeyi $\mathrm{p}<0,05$ olarak alınmıştır. Elde edilen verilerin analizinde, Excel ve SPSS 21.00 sosyal bilimler için istatistik paket programı kullanılmış; betimleyici istatistikler için yüzde dağılımları, frekans ve korelasyon analizi uygulanmış; güvenirlik analizi için anova analizi ve t testi yapılmıştır.

\section{Araştırma Bulguları}

\section{Alaeddin Keykubad Kampüsü}

1975 yılında kurulan Selçuk Üniversitesi, 1982 yılında Alaeddin Keykubad Kampüsü'nün inşa edilmeye başlanmasıyla kampüse sahip olmuştur. Alaeddin Keykubad Kampüsü'nde;

- 20 fakülte,

- 3 yüksekokul,

- 4 meslek yüksekokulu,

- 1 konservatuvar,

- 6 enstitü,

- Rektörlüğe bağlı birimler,

- 44 araştırma ve uygulama merkezi,

- 17 koordinatörlük,

- Teknokent,

- İdari birimler, 
- Otoparklar, ulaşım ağı (yaya, bisiklet ve araç yolları, tramvay hatt1), yurtlar, lojmanlar, kütüphane, hastane, misafirhane, Erasmus Evi, cami, hobi bahçeleri, kapalı yüzme havuzu, kapalı spor salonu, spor tesisleri, stadyum, kültür merkezi, amfi, meydan, müze, 1sı merkezi, açı-yeşil alanlar, yeme-içme mekanları ve alış-veriş merkezleri de yer almaktadır (Şekil 2), (Şekil 3) (S.Ü., 2018a).

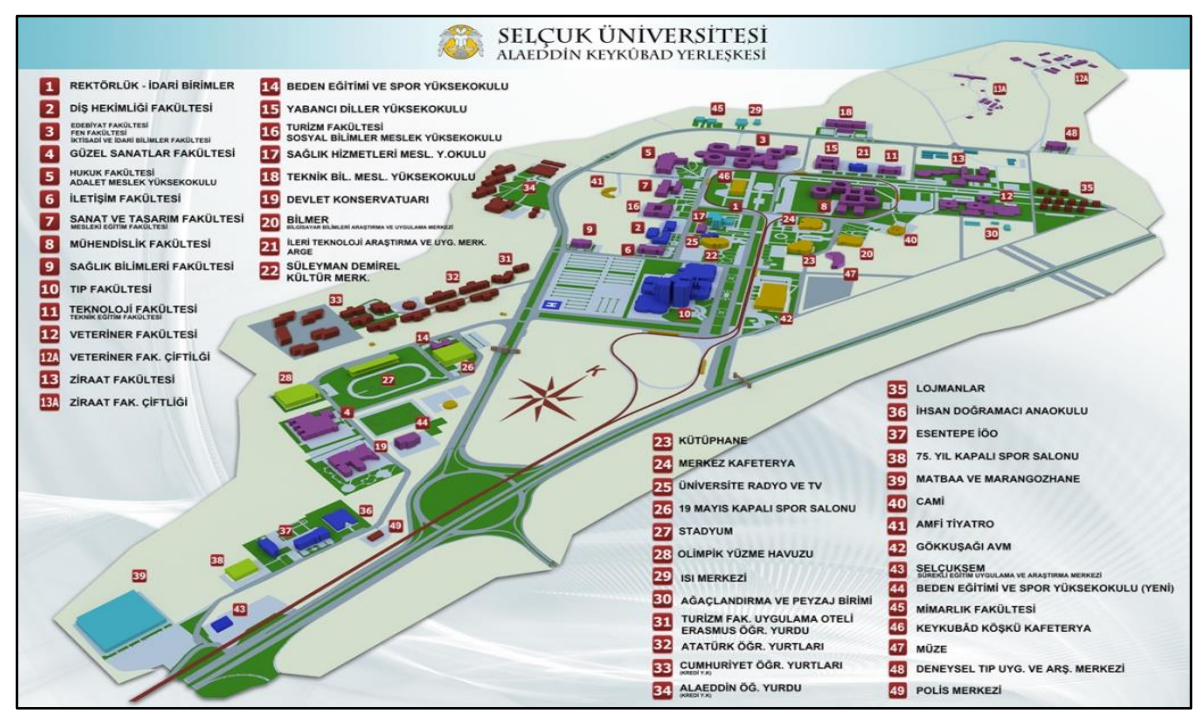

Şekil 2. Alaeddin Keykubad Kampüsü birimleri (S.ய̈., 2018a)

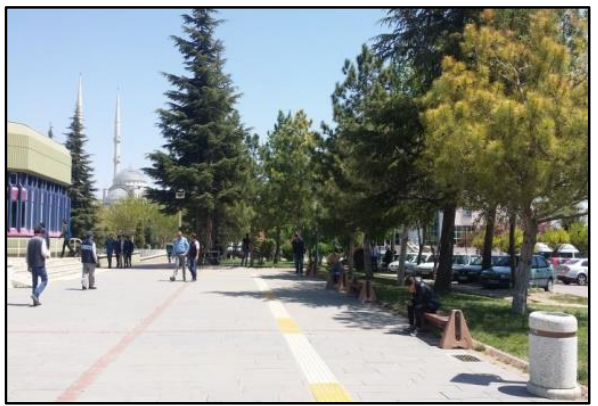

Yemekhane ve caminin çevresi

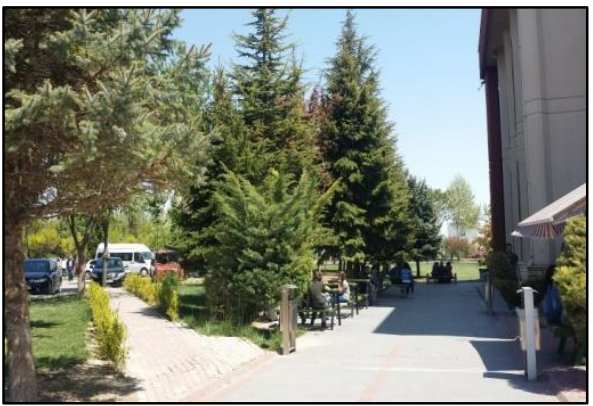

Kütüphanenin çevresi 


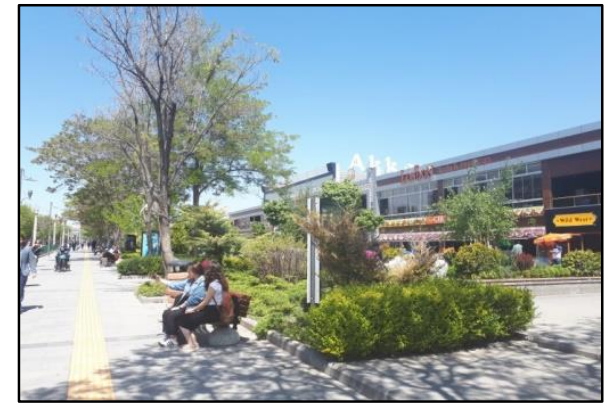

Gökkuşağı alış-veriş merkezi çevresi

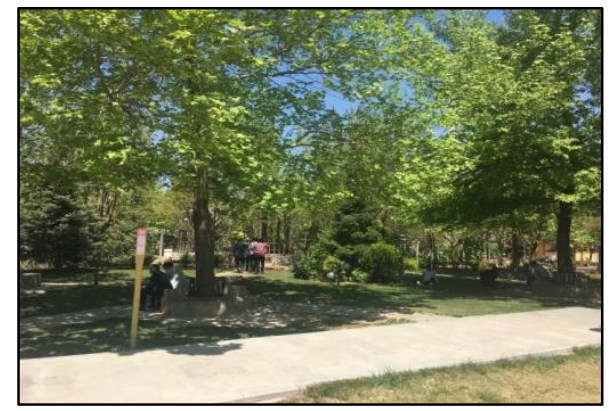

Yeşil alan

Şekil 3. Alaeddin Keykubad Kampüsü'nde yer alan ortak kullanım alanlan (Orijinal, 2018)

\section{Alaeddin Keykubad Kampüsü'nde güvenlik çalışmaları}

Selçuk Üniversitesi Genel Sekreter'e bağlı “Koruma ve Güvenlik Müdürlüğü", "Selçuk Üniversitesi Koruma ve Güvenlik Müdürlüğü Görev ve Çalışma Yönergesi" doğrultusunda Alaeddin Keykubad Kampüsü'nde koruma ve güvenlik hizmetlerini yürütmektedir. Bu doğrultuda Koruma ve Güvenlik Müdürlüğü'nün amacı, öğrencilerin eğitimini engelleme, çalışanları zorla işten alıkoyma, sabotaj, yangın, hırsızlık ve her türlü tehdit ve tehlikelere karşı güvenliklerinin sağlanması, yerleşke içerisinde suç işlenmesini önlemek amacıyla gerekli güvenlik tedbirlerini alarak, eğitim öğretimin sorunsuz olarak devam etmesini sağlamaktır. Selçuk Üniversitesi'nin "geleneği, gelecekle buluşturan bir Dünya üniversitesi olmak" ilkesi doğrultusunda, yerleşkelerinde teknolojik gelişme ve yeniliklerden faydalanarak güvenlik hizmetinin hızlı güvenli ve tutarlı bir şekilde yürütülmesini sağlamak, öğrenci, personel ve mezun memnuniyetini, insan haklarına saygılı, kaliteli, etkili ve teknolojik güvenlik hizmetleri sunarak örnek Koruma ve Güvenlik Müdürlügü olmayı hedef olarak benimsemiştir (S.Ü., 2018).

Koruma ve Güvenlik Müdürlüğ̈̈'nün amaç ve hedefi doğrultusunda Alaeddin Keykubad Kampüsü'nde gerçekleştirdiği güvenlik çalışmaları:

- Alaeddin Keykubad Kampüsü'nde güvenliği sağlamak amaciyla "Güvenlik İzleme ve Hiz İhlal Tespit Merkezi" (SAGİS) kurulmuştur.

- 2012 yılında çalışmalara başlanan ve 2013 yılı Eylül ayında hiz- 
mete giren merkez sayesinde kampüsün tamamına yakın kısmı izlenebilmektedir. Kampüsün tamamını 24 saat süreyle gözetim altında tutabilecek 346 kameralı MOBESE sistemi mevcuttur.

- Güvenlik Hizmetleri Şefliği bünyesinde oluşturulan izleme odasında sertifikalı güvenlik görevlileri tarafından takip edilen sistem kapsamında kampüs içinde plaka tanıma ve hız tespiti yapilmaktadir.

- SAGİS sadece kamera izleme sisteminden oluşmayıp kayıt ünitesi de mevcuttur. Sistem, kamera sayısı ve kayıt kapasitesi arttırılabilecek şekilde tasarlanmıştır.

- Ana girişte plaka okuma sistemi mevcuttur.

- 4 ana giriş-çıkış kapısında (Şekil 4) özel güvenlik personeli görev yapmaktadır (S.Ü., 2018).

Alaeddin Keykubad Kampüsü'nde gündüz ve gece yapılan alan çalışması sonucunda mevcut durumda güvenlik açığı oluşturan yerler ve durumlar belirlenmiştir. Alan çalışması sonuçlarına göre:

- 4 ana giriş-çıkış kapısında (Şekil 4) güvenlik personeli görev yapmakta ancak kampüse girişlerde araç ve yaya kontrolü yapılmamaktadır. Tramvayla kampüse gelen ve öğrenci olmayan kişiler kontrol edilmemektedir.

- Plaka tanıma ve plaka okuma sistemi olmasına rağmen kampüse girişte kontrol yapılmaması kampüsün tamamı ve kişiler üzerindeki hakimiyeti zorlaştırmaktadır.

- Kampüsün 4 ana giriş-çıkış kapısının çevresinde kampüsü tanımlayan sınır elemanları (Şekil 5) mevcut iken kampüsün kuzey ve batısındaki sınır elemanları sadece tel çitten oluşmaktadır.

- Kampüsün kuzey ve batısındaki tali giriş-çıkışlarda tanımlı bir giriş takı olmayıp tamamen kontrolsüzdür.

- Ardıçlı ve Yükselen Mahallesi'ne kampüsten ulaşım sağlanmakta; toplu taşıma araçları ve özel araçlar kampüs içinden geçen yolu kullanmaktadır. Bu durum kampüsteki en büyük güvenlik zaafiyetini oluşturmaktadır.

- Selçuklu Tip Fakültesi Hastanesi ve Diş Hekimliği Fakültesi Hastanesi'ne gelen hasta ve yakınları, kampüste Gökkuşağı ve Köşk Alış-Veriş Merkezi ile yeşil alanları kullanmaktadır. 


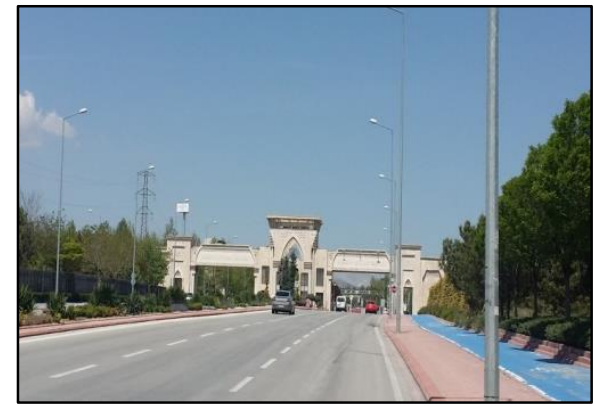

Alaeddin Keykubad Kapısı

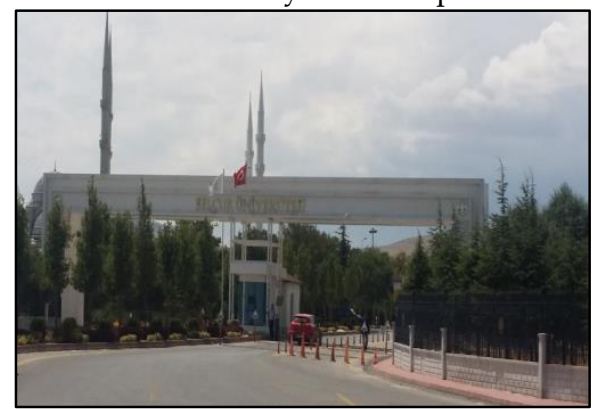

Aliya İzzet Begoviç Kapısı

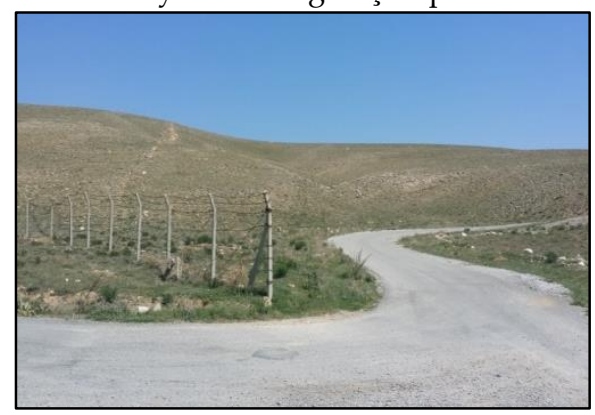

Tali giriş-çıkış kapıları

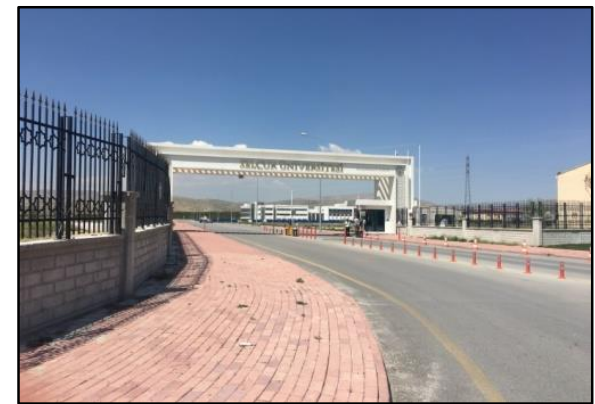

Kılıçarslan Kapısı

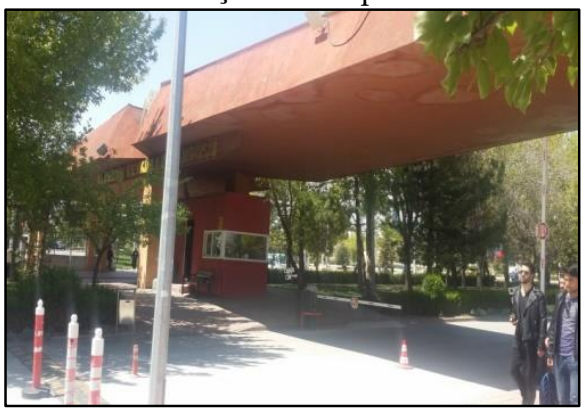

Mesnevi Kapısı

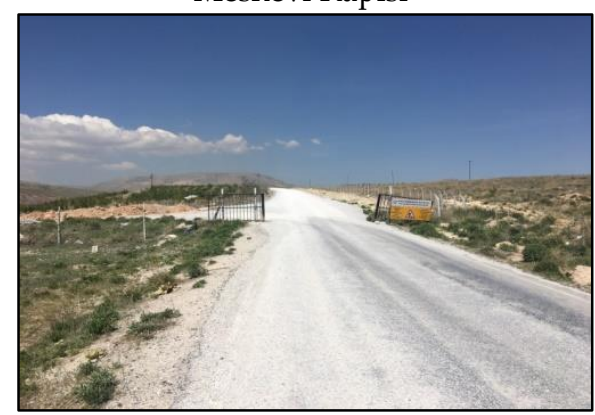

Şekil 4. Alaeddin Keykubad Kampüsü ana ve tali giriş-çıkış kapıları (Orijinal, 2018)

- $\quad$ Öğrenci olmayan kişiler özellikle akşam ve hafta sonlarında boş zamanlarını geçirmek için kampüse çok rahatlıkla araçla veya yaya olarak girmekte ve öğrencilerle aynı mekanları kullanmaktadir.

- Kampüste başıboş köpekler bulunmaktadır.

- Kampüste işlevi bilinmeyen ve işlevsiz mekanlar bulunmaktadır. 
- Bakımsız ve köhne mekanlar bulunmakta; böyle mekanlar suç ve suçlular için zemin hazırlamaktadır.

- Ağaç ve çalılar, yer yer görüşü kapatarak kör noktalar (Şekil 6) oluşturmaktadır.

- Yer yer kampüste aydınlatma yetersiz kalmakta; özellikle bitkilerin yoğun olduğu yerlerde hava karardığında karanlık-loş bölgeler oluşmaktadır.

- Patika yollar bulunmakta ve bu yollarda aydınlatma elemanları olmadığı için karanlıktır.
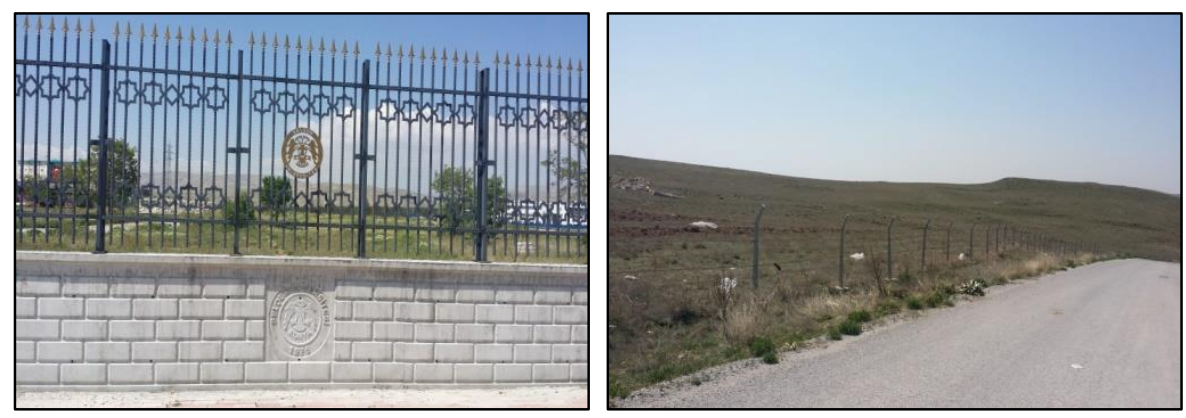

Şekil 5. Kampüs sınır elemanları (Orijinal, 2018)
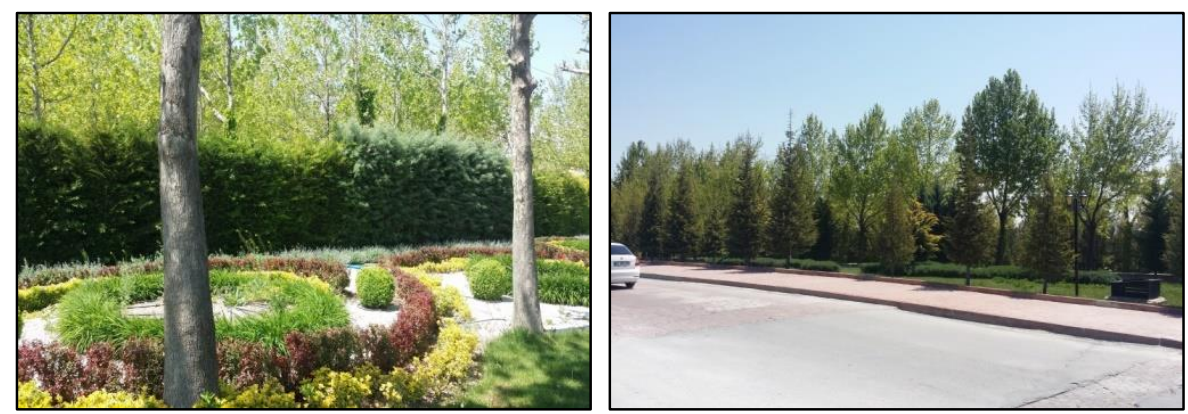

Şekil 6. Ă̆aç ve çalıların görüşü kapatarak oluşturduğu kör noktalar (Orijinal, 2018)

\section{Anket Verilerinin Analizi}

Kişisel bilgiler: Çalışmaya katılan 225 öğrenciden \%64,9'unu (146) kız öğrenciler, \%35,1'ini (79) erkek öğrenciler oluşturmaktadır. Cinsiyet de- 
ğişkenine göre en çok kız öğrenciler katılım göstermiştir. Anket, öğrencilerin tamamen gönüllü katılımları ile yapıldığı için kız öğrencilerin yüksek oranda katılımı, kız öğrencilerin güvenlik konusunda daha duyarlı, hassas ve ilgili olduğunu ortaya koymaktadır. Çalışmaya katılan öğrencilerin \%2,2'si 18 yaşında, \%12,9'u 19 yaşında, \%15,1'i 20 yaşında, \%22,2'si 21 yaşında, \%16'sı 22 yaşında, \%10,2'si 23 yaşında, \%2,7'si 24 yaşında, \%3,6'sı 25 yaşında, \%15,1'i ise 26 ve üstü yaşındadır.

Öğrencilerin eğitim gördükleri enstitü, fakülte, yüksekokul, meslek yüksekokulu ve konservatuara göre dağılımları Tablo 1.'de verilmiştir. Tablo 1.'de de görüldüğü gibi ankete farklı akademik birimlerden geniş bir katılım sağlanmıştır.

Kampüste güvenlik algısı: Öğrencilerin \%45,8'i genellikle kampüste güvende ve rahat hissettiğini ve $\% 36,4$ ü kampüsün fiziki çevresinden memnun olduğunu belirtmiştir. \%42,7'si gündüz kampüste genellikle; $\% 39,5$ 'i ise her zaman rahatça yürüyebildiğini ifade etmiştir. Gece ise $\% 18,2$ 'si asla; \%21,3'ü nadiren; \%27,1'i bazen; \%25,8'i ise genellikle rahatça yürüyebildiğini belirtmiştir (Tablo 2). Tablo 2 incelendiğinde önermelere katılma oranı genellikle kampüsün güvenli olarak algılandığını göstermektedir.

Öğrencilerin \%34,2'si bazen polis veya güvenlikten yardım alabileceğini düşünmektedir. Kampüs güvenliğinin devriye gezmesi öğrencilerin \% 30,2'sinin genellikle güvende olduğunu hissettirmektedir. Ayrıca öğrencilerin \%33,3'ü bazen üniversite yönetiminin kampüsü güvenli hale getirmek için gerekenleri yapmakta olduğunu belirtmiştir.

Çalışmaya katılan öğrencilerin \%8,9'u hazırlık sınıfı, \%19,6'sı 1. sınıf, $\% 17,8^{\prime}$ i 2. sinıf, $\% 20,9^{\prime}$ u 3. sınıf, $\% 26,2^{\prime}$ si 4. sinıf, \%2,7'si 5. sinıf ve \%4'ü 6. siniftadir.

$3,4,5$ ve 6 . sınıftaki öğrencilerin yeni öğrencilere (hazırlık, 1 ve 2 . sinıf) göre kampüsü daha iyi tanıdıkları için kampüsü güvenli algılayacakları düşünülmüştür. Bu nedenle öğrencilerin sınıflarına göre kampüste güvenlik algısı arasında farklılık gösterip göstermediğini belirlemek için tek yönlü anova testi yapılmıştır. Yapılan test sonucu anlamlı çıkmamıştır. Sonuçların anlamlı çıkmaması ise öğrencilerin aynı görüşte olduğunu ifade etmektedir ( $p>0,05)$. Bu sonuç yaşanılan yeri tanımanın güvenlik algısını olumlu etkilediği fikrini doğrulamadığını göstermektedir. 
Çalışmaya katılan öğrencilerin \%52,4'ü evde, \%28'i kampüs içerisindeki yurtlarda ve \%19,6'sı da kampüs dışındaki yurtlarda barınmaktadır. Öğrencilerin \%72'si kampüs dışında barınmaktadır. Bu durum öğrencilerin belirli zamanlarda kampüste bulunduğunu göstermektedir.

Tablo 1. Eğitim gördükleri akademik birimlere göre öğrencilerin dă̆ılımı

\begin{tabular}{|c|c|c|c|}
\hline \multicolumn{2}{|l|}{ Akademik Birimler } & $\begin{array}{r}\text { Yüzde } \\
(\%)\end{array}$ & $\begin{array}{r}\text { Say1 } \\
(\mathrm{N})\end{array}$ \\
\hline \multirow{2}{*}{ Enstitü } & Fen Bilimleri Enstitüsü & 3,6 & 8 \\
\hline & Sosyal Bilimler Enstitüsü & 2,7 & 6 \\
\hline \multirow{19}{*}{ Fakülte } & Diş Hekimliği & 4,9 & 11 \\
\hline & Edebiyat & 4,9 & 11 \\
\hline & Eğitim & 0,4 & 1 \\
\hline & Fen & 0,4 & 1 \\
\hline & Güzel Sanatlar & 0,9 & 2 \\
\hline & Hukuk & 12,5 & 28 \\
\hline & İktisadi ve İdari Bilimler & 8 & 18 \\
\hline & İletişim & 7,1 & 16 \\
\hline & İslami İlimler & 0,4 & 1 \\
\hline & Mimarlık $^{3}$ & 10,2 & 23 \\
\hline & Mühendislik & 3,6 & 8 \\
\hline & Sağlık Bilimleri & 2,7 & 6 \\
\hline & Sanat ve Tasarım & 1,3 & 3 \\
\hline & Spor Bilimleri & 1,3 & 3 \\
\hline & Teknoloji & 1,3 & 3 \\
\hline & Tip & 8,8 & 20 \\
\hline & Turizm & 1,3 & 3 \\
\hline & Veteriner & 3,6 & 8 \\
\hline & Ziraat & 7,1 & 16 \\
\hline \multirow{3}{*}{ Meslek Yüksekokulu } & Sağllk Hizmetleri & 0,9 & 2 \\
\hline & Sosyal Bilimler & 1,8 & 4 \\
\hline & Teknik Bilimler & 4,4 & 10 \\
\hline \multirow{2}{*}{ Yüksekokul } & Sivil Havacılık & 1,7 & 4 \\
\hline & Yabancı Diller & 2,7 & 6 \\
\hline Konservatuar & Dilek Sabancı Devlet Konservatuarı & 1,3 & 3 \\
\hline \multicolumn{2}{|l|}{ Toplam } & 100 & 225 \\
\hline
\end{tabular}

${ }^{3}$ 2017-2018 akademik yılından itibaren Mimarlık Fakültesi, Alaeddin Keykubat Kampüsünden ayrılmıştır. Bu nedenle Mimarlık Fakültesi'nin sadece 3. ve 4. sınıf öğrencilerine anket uygulanmıştır. 
Tablo 2. Kampüste güvenlik algısı

\begin{tabular}{lccccc}
\hline Kampüste güvenlik algısı & Asla & Nadiren & Bazen & Genellikle & $\begin{array}{c}\text { Her } \\
\text { zaman }\end{array}$ \\
\hline $\begin{array}{l}\text { Kampüste kendimi güvende } \\
\text { hissediyorum. }\end{array}$ & $\% 6,2$ & $\% 11,1$ & $\% 20,4$ & $\% 45,8$ & $\% 16,4$ \\
$\begin{array}{l}\text { Kampüste kendimi rahat his- } \\
\text { sediyorum. }\end{array}$ & $\% 2,2$ & $\% 11,6$ & $\% 23,1$ & $\% 45,8$ & $\% 17,3$ \\
$\begin{array}{l}\text { Kampüsün fiziki çevresinden } \\
\text { memnunum. }\end{array}$ & $\% 11,1$ & $\% 13,8$ & $\% 27,1$ & $\% 36,4$ & $\% 11,6$ \\
$\begin{array}{l}\text { Gündüz kampüste rahatça } \\
\text { yürüyebilirim. }\end{array}$ & $\% 2,2$ & $\% 4$ & $\% 11,6$ & $\% 42,7$ & $\% 39,5$ \\
$\begin{array}{l}\text { Gece kampüste rahatça yürü- } \\
\text { yebilirim. }\end{array}$ & $\% 18,2$ & $\% 21,3$ & $\% 27,1$ & $\% 25,8$ & $\% 7,6$ \\
$\begin{array}{l}\text { Gerekirse polis veya güvenlik- } \\
\text { ten yardım alabilirim. }\end{array}$ & $\% 9,8$ & $\% 19,6$ & $\% 34,2$ & $\% 24,4$ & $\% 12$ \\
$\begin{array}{l}\text { Kampüs güvenliğinin devriye } \\
\text { gezmesi güvende olduğumu } \\
\text { hissettir. }\end{array}$ & $\% 8,9$ & $\% 15,1$ & $\% 21,8$ & $\% 30,2$ & $\% 24$ \\
$\begin{array}{l}\text { Üniversite yönetimi kampüsü } \\
\text { güvenli hale getirmek için } \\
\text { gerekenleri yapmaktadır. }\end{array}$ & $\% 19,1$ & $\% 16,4$ & $\% 33,3$ & $\% 20,9$ & $\% 10,2$ \\
\hline
\end{tabular}

Kampüste güvenlik düzeyi gece ve gündüz farklılığına bağlı olarak ele alınmış; öğrencilerin $\% 44,9^{\prime} \mathrm{u}$ gündüz güvenli algılarken; $\% 34,7^{\prime}$ si gece bazen güvenli-bazen güvensiz, $\% 24,4$ 'ü ise gece güvensiz olarak algıladığını belirtmiştir (Tablo 3).

Güvenlik, öznel bir duygu ve algıdır. Bu nedenle değişken bir özelliğe sahiptir. Yaş, cinsiyet, gece-gündüz zaman farkı, içinde bulunulan mekan, sosyo-ekonomik ve kültürel özelliklere göre farklılık göstermektedir. Cinsiyet değişkenine göre kampüste güvenlik düzeyi arasında farkl1lık olup olmadığını belirlemek için $t$ testi yapılmıştır. Yapılan analiz sonucunda cinsiyet ile kampüste güvenlik düzeyi arasında anlamlı bir ilişki olduğu görülmüştür. Sonuçların anlamlı çıkması katılımcıların görüş farklılığını ifade etmektedir ( $\mathrm{p}<0,05)$. Erkek öğrencilerin \%59,4'ü kampüsü gece güvenli algıladığını belirtirken kız öğrencilerde bu oran erkek öğrencilere göre daha düşük olup \%46,7'dir. Kız öğrencilerin \%66,8'i kampüsü gündüz güvenli algıladığını belirtirken erkek öğrencilerde bu oran kız öğrencilere göre daha fazla olup $\% 71,1^{\prime}$ dir. 
Tablo 3. Kampüste güvenlik düzeyi

\begin{tabular}{llllll}
\hline $\begin{array}{l}\text { Kampüste } \\
\text { güvenlik } \\
\text { düzeyi }\end{array}$ & $\begin{array}{l}\text { Çok } \\
\text { güvenli }\end{array}$ & Güvenli & $\begin{array}{l}\text { Bazen güvenli/ } \\
\text { bazen güvensiz }\end{array}$ & Güvensiz & $\begin{array}{l}\text { Çok gü- } \\
\text { vensiz }\end{array}$ \\
\hline $\begin{array}{l}\text { Kampüsün } \\
\text { gündüz gü- } \\
\text { venliği }\end{array}$ & $\% 7,1$ & $\% 44,9$ & $\% 33,8$ & $\% 11,1$ & $\% 3,1$ \\
$\begin{array}{l}\text { Kampüsün } \\
\text { gece güven- }\end{array}$ & $\% 2,2$ & $\% 17,8$ & $\% 34,7$ & $\% 24,4$ & $\% 20,9$ \\
liği
\end{tabular}

Kampüste güvensiz hissetme nedenleri: Kampüste güvensiz hissetme nedenleri açısından;

- Kampüse gelen yabanclar $(\% 47,1)$, şüpheli kişiler ve $(\% 40)$ başıboş köpekler $(\% 34,2)$ çok etkili nedenler arasında yer almaktadir.

- Kampüsün geniş bir alan kaplaması $(\% 38,2)$ ve suç korkusu $(\% 26,2)$ etkili,

- Kampüsün yerleşim düzeni (\%29,8), yönlendirme eksikliği, yön bulamama $(\% 30,7)$ ve işlevi bilinmeyen yerler $(\% 26,2)$ hem etkili hem de etkisiz,

- Patika yollar $(\% 28,4)$ ise etkisiz olarak nitelendirilmiştir (Tablo 4).

Tablo 4. Kampüste güvensiz hissetme nedenleri

\begin{tabular}{|c|c|c|c|c|c|}
\hline $\begin{array}{l}\text { Kampüste güvensiz his- } \\
\text { setme nedenleri }\end{array}$ & $\begin{array}{l}\text { Çok } \\
\text { etkili }\end{array}$ & Etkili & $\begin{array}{c}\text { Bazen etkili/ } \\
\text { bazen etki- } \\
\text { siz }\end{array}$ & Etkisiz & $\begin{array}{l}\text { Hiç etkili } \\
\text { değil }\end{array}$ \\
\hline Kampüse gelen yabancılar & $\% 47,1$ & $\% 30,2$ & $\% 12,4$ & $\% 6,7$ & $\% 3,6$ \\
\hline $\begin{array}{l}\text { Kampüsün geniş bir alan } \\
\text { kaplaması }\end{array}$ & $\% 27,1$ & $\% 38,2$ & $\% 16$ & $\% 8,9$ & $\% 9,8$ \\
\hline Başıboş köpekler & $\% 34,2$ & $\% 25,3$ & $\% 17,3$ & $\% 12,4$ & $\% 10,7$ \\
\hline $\begin{array}{l}\text { Kampüsün yerleşim dü- } \\
\text { zeni }\end{array}$ & $\% 15,1$ & $\% 25,3$ & $\% 29,8$ & $\% 20,4$ & $\% 9,3$ \\
\hline Yönlendirme eksikliği & $\% 12,8$ & $\% 20$ & $\% 30,7$ & $\% 25,8$ & $\% 10,7$ \\
\hline İşlevi bilinmeyen yerler & $\% 17,3$ & $\% 25,8$ & $\% 26,2$ & $\% 24,9$ & $\% 5,8$ \\
\hline Patika yollar & $\% 14,7$ & $\% 21,3$ & $\% 26,2$ & $\% 28,4$ & $\% 9,3$ \\
\hline Şüpheli kişiler & $\% 40$ & $\% 31,1$ & $\% 14,7$ & $\% 12$ & $\% 2,2$ \\
\hline Suç korkusu & $\% 31,6$ & $\% 26,2$ & $\% 21,3$ & $\% 15,6$ & $\% 5,3$ \\
\hline
\end{tabular}


Selçuklu Tıp Fakültesi Hastanesi ve Diş Hekimliği'ne tedavi için gelen hasta ve yakınları kampüse gelen yabancıların büyük bir kısmını oluşturmaktadır. Kampüse gelen bu kişiler öğrencilerle aynı ortak mekanları (Gökkuşağ1 ve Köşk alış-veriş merkezi, yeme-içme mekanları, hastane ve yakın çevresindeki yeşil alanları) kullanmaktadır. Kampüse gelen yabancılar, kız öğrenciler açısından \%84,5 güvensiz hissetme nedenidir.

Kız öğrenciler açısından dış görünüşünden öğrenci olmadığı anlaşılan ve hangi amaçla kampüse geldiği anlaşılmayan şüpheli kişiler de $\% 80,9$ oranında güvensiz hissetmekte en etkili faktördür. Ayrıca kampüsün geniş bir alan kaplaması kız öğrenciler için $(\% 76,4)$ güvensiz hissettiren nedenler arasında 3. sırada yer almaktadır. Erkek öğrenciler açısından \%77,7'si kampüse gelen yabancılar; \%75,1'i şüpheli kişiler ve \%67,3'ü için başıboş köpekleri güvensiz hissetme nedenleri arasında belirtmişlerdir (Tablo 5).

Cinsiyete göre kampüste güvensiz hissetme nedenlerini gösteren Tablo 5 incelenirse kız öğrencilerin erkek öğrencilere göre güvensiz hissetme nedenleri daha yüksek çıkmıştır. Güvensizlik, bireyin içinde bulunduğu durumu algilama sonrasinda korku, risk, tehdit ve tehlike kavramlarıyla birlikte ifade edilmektedir. Suç korkusu ise bir mekanda güvensiz hissetmek için en etkili nedendir. Özellikle ankete katılan kız öğrencilerin \%78'i; erkek öğrencilerin ise \%62,5'i fiziksel, sözlü, cinsel saldırı ve hırsızlık vb. suç korkusunun kampüste güvensiz hissetme nedenleri arasında etkili olduğunu belirtmiştir. Bu sonuç ise kadınların, erkeklere oranla daha fazla suç korkusu taşıdığı fikrini kampüsteki öğrenciler için de geçerli kılmaktadır. Bu çalışmada olduğu gibi literatürdeki tüm çalışmalarda kadınların suç korkusunun erkeklere oranla daha fazla olduğu görülmektedir (Özaşçlar, 2015). Bu çalışmada erkek öğrenciler arasında da kampüste suç korkusu oldukça yüksek $(\% 62,5)$ çıkmıştır.

Güvenlik, öznel bir alg1 olarak içinde bulunulan mekanın özelliklerine göre farklılık gösterdiği için kampüste güvenli ve güvensiz hissettiren yerler belirlenmiştir. Öğrencilerden kampüste güvenli ve güvensiz hissettiren yerler hakkında 3 seçenek işaretlemeleri istenmiş; bu doğrultuda 225 öğrenciden güvenli hissettiren yerler için 606; güvensiz hissettiren yerler için 608 cevap alınmıştır (Tablo 6). 
Tablo 5. Cinsiyete göre kampüste güvensiz hissetme nedenleri

\begin{tabular}{|l|l|c|}
\hline Kampüste güvensiz hissetme nedenleri & Cinsiyet & Yüzde (\%) \\
\hline \multirow{2}{*}{ Kampüse gelen yabancılar } & Kız & 84,5 \\
\cline { 2 - 3 } & Erkek & 77,7 \\
\hline \multirow{2}{*}{ Kampüsün geniş bir alan kaplaması } & Kız & 76,4 \\
\cline { 2 - 3 } & Erkek & 66,1 \\
\hline \multirow{2}{*}{ Başıboş köpekler } & Kız & 74,5 \\
\cline { 2 - 3 } & Erkek & 67,3 \\
\hline \multirow{2}{*}{ Kampüsün yerleşim düzeni } & Kız & 65,2 \\
\cline { 2 - 3 } & Erkek & 59,7 \\
\hline \multirow{2}{*}{ Yönlendirme eksikliği/yön bulamama } & Kız & 64,1 \\
\cline { 2 - 3 } & Erkek & 51,6 \\
\hline \multirow{2}{*}{ İ̧levi bilinmeyen yerler } & Kız & 68,6 \\
\cline { 2 - 3 } & Erkek & 57,7 \\
\hline \multirow{2}{*}{ Patika yollar } & Kiz & 65,4 \\
\cline { 2 - 3 } & Erkek & 51,9 \\
\hline \multirow{2}{*}{ Şüpheli kişiler } & Kiz & 80,9 \\
\cline { 2 - 3 } & Erkek & 75,1 \\
\hline \multirow{2}{*}{ Suç korkusu } & Kız & 78 \\
\cline { 2 - 3 } & Erkek & 62,5 \\
\hline
\end{tabular}

Kampüste güvenli hissettiren ilk 3 yer sirasıyla;

- \%20,3 aydınlık yerler,

- $\% 17,5$ kalabalık yerler,

- \%17,2 ortak kullanım alanları olan Gökkuşağı alış-veriş merkezi, kütüphane, yemekhane, spor tesisleri vb. çevresidir (Tablo 6).

Güvensiz hissettiren yerler siralamasında ise;

- \%19,1 kalabalık yerler,

- $\% 17,1$ bakımsız-köhne yerler,

- \%16,1 giriş-çıkış noktaları ilk 3 sırada yer almaktadır (Tablo 6).

Mekanın bazı nitelikleri, hem güvenli hem de güvensiz algılamaya neden olmaktadır. Kalabalık yerler, güvenli hissettiren yerler sıralamasinda ilk sirada iken güvensiz hissettiren yerler siralamasında 2. sirada yer almaktadır. Bu durum güvenlik algısının yaş, cinsiyet, psikolojik durum, zaman ve mekansal faktörler nedeniyle değişken olmasının bir sonucudur. Bir mekanın büyüklügüne kıyasla bu mekanda bulunan kişilerin sayısına göre tanımlanan yoğunluk olarak ifade edilebilecek kalaba- 
lık, insanlarda farklı algılar oluşturur. Duruma ilişkin olumsuz duyguların yanı sıra olumlu duyguları ve bunların psikolojik sonuçlarını da ortaya çıkarır. Kalabalık, bazı kişilerde çok sayıda kişiyle birlikte bulunmanın yol açtığı stres, bulunulan yer üzerinde kontrol eksikliği algisı, istenen şekilde hareket edememeye bağlı güvensizlik algısına neden olabilir. Bazı kişilerde ise insanlarla aynı mekanda olmak güven ve tehlike anında çevredekilerden yardım isteme imkanı verebilmektedir.

Enstitü, fakülte, meslek yüksekokulu, yüksekokul ve konservatuarın yakın çevresi \%0,5 güvensiz olarak nitelendirilmiştir. Anket sonucu ve gözlemler doğrultusunda öğrencilerin eğitim binalarının yakın çevresini güvenle ve rahatlıkla kullandıklarını söylemek mümkündür.

Özellikle ağaç ve çalıların yoğun olduğu yerler için öğrencilerin \%8,4'ü; bakımsız ve köhne yerler için öğrencilerin \%17,1'i güvensiz hissettiren yerler arasında belirtmiştir. Bu durum güvenlik algısında peyzaj tasarımı ve yeşil alanların bakımlı olmasının etkisini ortaya koymaktadır. Mekanın düzenli, temiz ve bakımlı olmasına yönelik izlenimler güvenlik algısını olumlu etkilemekte ve suç olaylarını azaltmada etkilidir.

Tablo 6. Kampüste güvenli ve güvensiz hissettiren yerler

\begin{tabular}{|c|c|c|c|c|c|}
\hline $\begin{array}{l}\text { Kampüste güvenli hisset- } \\
\text { tiren yerler }\end{array}$ & $\mathbf{N}$ & $\%$ & $\begin{array}{l}\text { Kampüste güvensiz his- } \\
\text { settiren yerler }\end{array}$ & $\mathbf{N}$ & $\%$ \\
\hline Giriş-çıkış noktaları & 42 & 6,9 & $\begin{array}{l}\text { Giriş-çıkış noktaları (kont- } \\
\text { rol yok) }\end{array}$ & 98 & 16,1 \\
\hline Aydınlık yerler & 123 & 20,3 & Karanlık yerler & 52 & 8,6 \\
\hline Kalabalık yerler & 106 & 17,5 & Kalabalık yerler & 118 & 19,4 \\
\hline Sakin yerler & 22 & 3,6 & Sakin yerler & 58 & 9,5 \\
\hline Net görülen yerler & 80 & 13,2 & Net görülmeyen yerler & 78 & 12,8 \\
\hline $\begin{array}{l}\text { Ağaç ve çalıların az oldu- } \\
\text { ğu yerler }\end{array}$ & 9 & 1,5 & $\begin{array}{l}\text { Ağaç ve çalıların yoğun } \\
\text { olduğu yerler }\end{array}$ & 51 & 8,4 \\
\hline Tramvay durakları & 65 & 10,7 & Tramvay durakları & 7 & 1,2 \\
\hline Ortak kullanım alanları & 104 & 17,2 & Ortak kullanım alanları & 13 & 2,1 \\
\hline Bakımlı ve temiz yerler & 25 & 4,1 & Bakımsız ve köhne yerler & 104 & 17,1 \\
\hline $\begin{array}{l}\text { Güvenlik kameraları olan } \\
\text { yerler }\end{array}$ & 22 & 3,6 & Devam eden inşaatlar & 26 & 4,3 \\
\hline $\begin{array}{l}\text { Eğitim binalarının yakın } \\
\text { çevresi }\end{array}$ & 8 & 1,3 & $\begin{array}{l}\text { Eğitim binalarının yakın } \\
\text { çevresi }\end{array}$ & 3 & 0,5 \\
\hline Toplam & 606 & 100 & Toplam & 608 & 100 \\
\hline
\end{tabular}




\section{Sonuç ve Öneriler}

Bu çalışmanın sonuçları, Selçuk Üniversitesi, Alaeddin Keykubad Kampüsü öğrencilerinin kampüsün fiziksel çevresine yönelik güvenlik algılarını ortaya koymaktadır. Alaeddin Keykubad Kampüsü'nde güvenlik alg1sı öğrencilerin kampüsteki yaşam ve eğitim kalitesi, akademik başarı, öğrenciler arası ilişkiler ve sosyal etkinlikler açısından oldukça etkilidir. Kampüs öğrencilerinin güvenlik algılarını anlamak, kampüsün güvenliği açısından etkili önlemlerin alınması için çok önemlidir. Bu bağlamda Alaeddin Keykubad Kampüsü için güvenlik önerileri:

- Aynı veya benzer bir çalışma akademik ve idari personel için de uygulanabilir. Böylece kampüs kullanıcılarının güvenlik algılarını ve korkularını anlayarak güvenli bir kampüs için çözümler üretmek daha etkili olacaktır.

- Kurulduğu yıldan itibaren parça parça tasarlanan ve uygulanan Alaeddin Keykubad Kampüsü'nün peyzajı, öğrenciler ile akademik ve idari personelin güvenlik konusundaki kaygılarını giderecek şekilde bir bütün olarak ele alınmalıdır.

- Kampüs sinırlarının net bir şekilde algılanacağı sınır elemanları ile bütün kampüsün sınırları çevrelenmelidir.

- Tali giriş-çıkış kapılarının tanımlı hale getirilerek kamera ile kontrolü sağlanmalıdır. Tali giriş-çıkış kapılarının gözlemi için kullanılacak kameralar, önleyici ve caydırıcı olmasının yanı sıra olayların tespiti için de kullanılabilir.

- Plaka okuma sistemi olmasına rağmen ana giriş-çıkış kapılarında kampüse gelen araç ve yaya kontrolünün yapılası kampüse kötü niyetlerle gelen kişiler için caydırıcı nitelikte olacaktır. Ayrıca araç ve yayaların bire bir kontrol edilerek kampüse alınması kampüsün tamamı üzerindeki hakimiyeti de arttıracaktır.

- Kampüste erişim kontrolü sağlanmalıdır. Kampüse amaçsız gelen kullanıcıların erişimini engellemek için giriş-çıkış kapılarında kontrol etmenin yanı sıra diğer fiziksel tasarım elemanları da kullanılabilir.

- Güvenlik kontrol sistemleri (personel, ziyaretçi/misafir ve öğrenci giriş-çıkış takip sistemi, araç ve misafir kontrol sistemi) ve öğrenci yönetim sistemleri (turnike geçiş kontrol sistemi, 
yemekhane takip sistemi ve kiosk bilgilendirme sistemi) gibi akıllı kampüs çözümleri de kullanılabilir.

- Ağaç ve çalıların yoğun olduğu yerlerde özelikle gece görüşü sağlamak için aydınlatma yapılmalıdır. Ayrıca ağaç ve çalıların, görüşü engellememesi için bitkilerin formu dikkate alınarak budanabilir. Dış mekanların gözlemlenmesi, yeterli aydınlatma ve engelsiz görüş sağlayan peyzaj tasarımı ile geliştirilebilir. Böylece öğrencilerin çevreyi görmesi için imkan sağlanırken yabancı veya şüpheli kişilerin de gözlemlenmesi sağlanır.

- Alaeddin Keykubad Kampüsü'nde girişlerde kampüs yerleşim planı ile fakülte, yüksekokul, meslek yüksekokulu, konservatuvar, enstitü, diğer akademik ve idari birimler için yönlendirme levhaları yerleştirilmelidir.

- Fiziksel çevrenin niteliği bireylerin güvenlik duygusunu ve suç korkusunu belirlemektedir. Köhne ve bakımsız yerler, suç ve suçlular için zemin oluşturmakta; güvensizlik algısı ve suç korkusuna neden olmaktadır. Bu kapsamda köhne ve bakımsız yerler, öncelikle bakım programı içine alınarak kampüste köhne ve bakımsız yerlerin kalmamasına dikkat edilmelidir.

- Kampüste yanlış tasarım kararları nedeniyle işlevi bilinmeyen ve işlevsiz mekanlar ortaya çıkmıştır. Tanımsız mekanlarda bulunmak ise güvensizlik algısı ve suç korkusuna neden olmaktadır. Kampüste inceleme yapılarak işlevi bilinmeyen ve işlevsiz mekanlar, öğrencilerin istek ve ihtiyaçları doğrultusunda yeniden tasarlanmalıdır.

- Sokak hayvanları bütün kentlerde vardır ve küçük bir kent modeli olan Alaeddin Keykubad Kampüsü'nde de köpekler bulunmaktadır. Köpeklerin korku kaynağı olmaktan çok öğrenci, akademik ve idari personelin besleyip, sevgi ve ilgi gösterdiği, Veteriner Fakültesi'nin bakımını yaptığı evcil hayvanlar gibi benimsenmesi sağlanmalıdır.

- Karanlık bölgelerde yapılacak aydınlatma ile saldırıya karşı psikolojik bir caydırıcılık oluşturulabilir ve öğrencilerin çevreyi daha iyi algılaması sağlanabilir.

- Güvenli bir kampüs oluşturmak, tüm üniversite öğrencileri, akademik ve idari personelin katılımin gerektirir. Hatta 
kampüse gelen ziyaretçilerin de katılımı sağlanabilir. Tüm kampüs kullanıcılarının kişisel güvenlik konusunda bilgilendirilmesi sağlanabilir.

- Alaeddin Keykubad Kampüsünün fiziksel çevresini tanıtan bir rehber hazırlanarak kampüse yeni gelen öğrencilere kayit esnasında verilebilir. Öğrencilerin eğitim görecekleri kampüsü tanımaları, kapalı ve açı mekanları, ulaşım alternatiflerini öğrenmeleri sağlanabilir. Böylece kampüsün çevresinin tanınma ve aşina olma oranı arttıkça güvenlik algısı da olumlu yönde olacaktır.

- "Kampüs güvenlik rehberi" ve "kampüste güvenli yaşam rehberi" hazırlanabilir. Bu rehberler özellikle kampüse yeni kayıt yaptıran yerli ve yabancı öğrenciler için kampüsü tanıma ve kendini koruma konusunda yardımcı olacaktır.

- Risk analizi yapılmalı; belirli aralıklarla zaman içinde ortaya çıkan ve güvenlik sorunu oluşturan durumlar, olaylar, tehlikeler ve suçlar dikkate alınarak risk analizi güncellenmelidir. Güncel risk analizi doğrultusunda güvenlik önlemleri de yeni tehlike ve güvenlik sorunlarına uygun olarak yenilenebilir. 


\title{
EXTENDED ABSTRACT
}

\section{Students' Perceptions of Security Related to Alaeddin Keykubad Campus' Physical Environment}

\author{
Filiz Çelik ${ }^{*}$ R. Özge Gemici* - Esra Mirza** \\ *Selçuk University - ** Süleyman Demirel University
}

University campuses are close habitations in themselves where social reinforcements, such as administrative units, education buildings, dormitories, lodgements, guest house, conference hall, outdoor and indoor sports hall, religious construction, health facility, food-beverage and shopping places, transportation network, parking area and green spaces, are located. With this aspect, university campuses are like small cities. As in cities, causes like having a wide area of campuses, inadequate lighting, desolate and fusty places, stray animals, strangers and fear of crime make controlling of campus hard and indefensible. Therefore; from time to time, campuses become places in which safety need and fear of crime increase. Physical environment causes perception of security and insecurity, and influences peaceful atmosphere, quality of life, comfort level, layout and social control in campus. In addition to students, for the fact that academic and administrative personnel directly influence using of outer spaces, the perception of security is a factor affecting inhabitability and liveliness of campus.

University campuses are one of the most crucial places in every community. Campuses hold the burden of flourishing capable people for the next generations and are of utmost importance in providing different features besides education, like safety, security, vitality, health, etc. (Froughisaeid, 2018, s. 1). The issue of personal security is significant because of the design and layout of many university campuses and facilities. Campuses are often large open spaces and lack systematic access control, which may lead to a higher propensity for campus users to experience victimisation and fear (Waters, Neale ve Mears, 2005, s. 231). A secure campus is one that provides students the opportunity to pursue their academic potential in an environment free of discrimination, intimida- 
tion, or threat to physical or emotional well-being. The secure campus is one that responds to such threats and takes decisive, corrective action to eliminate them. A secure campus is one that is monitored for security, one where the various dimensions of the environment are routinely evaluated and adjustments are made as appropriate. Creating such an environment is an institutional responsibility and one that requires participation and commitment from multiple parties within the institution. This includes those in student affairs, often charged with the primary role of attending to the general welfare of the student body (Rund, 2002, s. 8).

The physical environment influences human behavior by creating limitations on the types of event that can occur in a particular area. Knowledge about human environments can be practically useful by providing critical clues for selecting and acting in settings, including college campuses. The same practicality can be associated with secondary school environments. Elements of the physical environment may permit or limit behaviors despite individual differences because the setting may determine and affect the inhabitants' behavior. Therefore, community living such as residence halls can discourage crime by the arrangement of bedrooms, hallways, exits, and lighting, while dark alleys can encourage criminal behaviors (Miller, 2011, s. 29).

University environments are mostly inhabited by young people. Meanwhile there are also various groups with diverse perceptions among those who use a university campus. Perception of security refers to the subjective experience and user's level of comfort. What a person perceives is what she/he sees as 'real' and it is this perception of reality that shapes her/his behavior (Froughisaeid, 2018, s. 1). Over the past fifty years the issue of campus safety has become a prevalent topic, and proved to be a complex one as well (Roberts, 2012, s. 18).

This research's aim is to determine the perceptions of security of students related to physical environment of Alaeddin Keykubad Campus in regard to the method of quantitative questioning based on the technique of survey and scale. The methodology of this study is guided by "The Handbook for Campus Safety and Security Reporting". In this study, the security of Alaeddin Keykubad Campus is based on the perception of students. The questionnaire has been implemented from 1 to 30 June of 
2018; via the internet that has been conducted with 225 students. Survey has been applied with willing students who have been selected according to the basis of random sampling. Using the program of SPSS 21 statistical analysis, the survey data have been computerized, analyzed with the technique of frequency distribution and the results has been explained. In direction with quantitative data, it is determined how physical features of campus affect the perceptions of security of students and secure-insecure places perceived by students in campus. In direction with obtained data, suggestions have been included to raise the perception of security of students in campus.

\section{Kaynakça/References}

Apak, S., Ülken, G. ve Ünlü, A. (2002). Yeni bir toplu konut yerleşmesinde 'güvenlik duygusunun' değerlendirilmesi. İTÜ Dergisi/a, $1(1), 65-72$.

Bedimo-Rung, A.L., Mowen, A. ve Cohen, D.A. (2005). The significance of parks to physical activity and public health a conceptual model. American Journal of Preventive Medicine, 28, 159-168.

Clery, J. (1986). The Jeanne Clery disclosure of campus security policy and campus crime statistics act. Accessed on $15^{\text {th }}$ June 2018 from https://www.feminist.org/education/pdfs/JeanneCleryActFullTex t.pdf.

Çelik, F. (2018). Kentsel açık-yeşil alanlarda güvenlik. İdealkent, 23(9), 5894.

Froughisaeid, N. (2018). Bir üniversite kampüsünün fiziksel ortamında güvenlik algısl: Orta Doğu Teknik Üniversitesi örneği. Yayımlanmamış Yüksek Lisans Tezi, ODTÜ Fen Bilimleri Enstitüsü, Ankara.

Kelly, B.T. ve Torres, A. (2006). Campus safety: Perceptions and experiences of women students. Journal of College Student Development, 47(1), 20-36.

Lenski, T.J. (1992). Students' perceptions of campus safety and the effect on intended precautionary behavior. Doctoral Dissertation, University of Vermont. 
Lenski, T.J., Meyers, H. ve Hunter, D. (1996). Understanding student's intentions to use safety precautions. NASPA Journal, 33(2), 82-93.

Maslow, A.H. (1943). A theory of human motivation. Psychological Review, 50, 370-396.

Miller, K.N. (2011). The relation of school and campus violence to students' perceptions of safety and precautionary behaviors". Doctoral Dissertation, Auburn University, Alabama.

Muscat, K.A. (2011). Rowan university students' perceptions of campus safety. Master Dissertation, Rowan University, Rowan.

Özaşçlar, M. (2015). Suç korkusu ve yakın çevre düzensizliği ilişkisi: Kırık cam teorisi. Suç Korkusu Kongresi, 22-23 Ekim 2014, Hermes Ofset, 329-347, Ankara.

Öztürk, O. (2014). Okul, kampüs güvenliği ve olası riskler. Güvenlik Yönetimi Dergisi, 16, 54-57.

Öztürk, O. (2015). Toplumsal davranış psikolojisi ve özel güvenliğin yeri. Güvenlik Yönetimi Dergisi, 27, 48-52.

Roberts, E. (2012). Keeping students safe: Student perceptions of campus safety at a mid-sized virginia university and the impact for prevention, response and risk reduction strategies. Masters Dissertation, James Madison University, Harrisonburg.

Rund, A.J. (2002). The changing context of campus safety. New Directions for Student Services, 99, 3-10.

Sözer, M.A. ve Clevenger, S. (2010). Üniversite kampüslerinde uygulanan tecavüz ve cinsel tacizi önleme eğitim programlarının etkililiği. Eskişehir Osmangazi Üniversitesi Sosyal Bilimler Dergisi, 11(1), 89-121.

S.Ü., Selçuk Üniversitesi, (2018). 2017-2018 Öğrenci İstatistikleri, Accessed on $5^{\text {th }}$ July 2018 from https://www.selcuk.edu.tr/ogrenci_isleri/birim/web/sayfa/ayrinti/2470/tr.

S.Ü., (2018a). Selçuk Üniversitesi resmi web sayfası, Accessed on $5^{\text {th }}$ July 2018 from http://www.selcuk.edu.tr/\#.

Şahin, D. (2016). Kent güvenliği algısı ve suç korkusu. $4^{\text {th }}$ International Congress on Urban and Environmental Issues and Policies, 20-22 October 2016, 105-109, İstanbul.

Uçkun, G. (2014). Güvenli kampüs var mı?. Güvenlik Yönetimi Dergisi, 16, 58-60. 
U.S. Department of Education, (2016). The handbook for campus safety and security reporting. Accessed on $15^{\text {th }}$ July 2018 from https://www2.ed.gov/admins/lead/safety/handbook.pdf.

U.S. Department of Education, (2018). CSS the campus safety and security. Accessed on $15^{\text {th }} \mathrm{Ju} 2018$ from https://ope.ed.gov/campussafety.

Waters, J., Neale, R.H. ve Mears, K. (2005). Perceptions of personal safety in relation to the physical environment of university campuses, CIB Joint Symposium on Advancing Facilities Management and Construction through Innovation, June 13-16 2005, 230-242, Helsinki.

\section{Kaynakça Bilgisi / Citation Information}

Çelik, F., Gemici, R. Ö. ve Mirza, E. (2018). Öğrencilerin Alaeddin Keykubad kampüsü fiziksel çevresine ilişkin güvenlik algıları. OPUSUluslararası Toplum Araştırmaları Dergisi, 9(16), 216-247. DOI: 10.26466/opus. 453200 